\title{
HUMAN RIGHTS POLICY UNDER THE CARTER ADMINISTRATION*
}

\author{
MARK L. SChNEIDER $\dagger$
}

I believe I speak for all of the participants in expressing appreciation to the International Law Society and Duke University School of Law for sponsoring this Symposium. What I have discovered is that there is a strong and renewed interest in the subject of human rights not only in the United States, but in other countries as well. Hopefully, we can explore not only what is being done, but what should be done in order to create a more effective U.S. human rights policy.

I shall review the first year of the Carter Administration's human rights policy, examine what has been done to implement that policy, discuss its results, and in so doing, raise some questions as to its future.

To begin, I have some good news to share with you, which I would like to announce in honor of this Symposium. Yesterday, the President submitted to the Senate for ratification four international human rights treaties: the International Convention on the Elimination of all Forms of Racial Discrimination, the International Covenant on Civil and Political Rights, the International Covenant on Economic, Social and Cultural Rights, and the American Convention on Human Rights. What is significant about this act is that all of these treaties had been sitting on government shelves between nine and thirteen years. Now the United States has recognized the importance of assuming its formal obligations under international human rights law.

Upon taking office, President Carter-following a theme struck early in his campaign-set a new course for American foreign policy. It was an effort to bring our foreign policy into line with our domestic values. It was a policy that grew out of a decade of rising disillusionment with the war in Viet Nam. It was a policy that grew out of a sense of shame when news photos showed governments to which we had shipped guns and rifles turn those weapons against their own people. It was a policy that grew out of an undercurrent of resentment on the part of the American people. But it was a policy based on actions and initiatives taken earlier.

For several years, non-governmental organizations in other countries had been urging governments to give a higher priority to human rights in foreign policy. In the United States, following Viet Nam and other events, Congress

\footnotetext{
* Lecture at the symposium entitled, Protecting the Right to Dissent, Duke University School of Law, February 24-25, 1978.

$\dagger$ Deputy Assistant for Human Rights and Humanitarian Affairs, Department of State.
} 
began to advocate a higher priority for human rights in foreign policy. From 1973 onward, Congress placed increasing restrictions on foreign assistance programs designed to insure that the programs were carried out in ways that promote human rights.

Now, after a year of the Carter Administration policy, it is appropriate to examine what has changed in the way decisions are made, whether decisions reflect new priorities, and if so, what impact they have had on the international community. First, I would like to assert what is not the case. The human rights policy of the Administration is not the final determinant of each and every foreign policy decision. However, neither have human rights interests been steamrolled out of the way by security or economic copcerns. The policy is neither a failure because all repression is not ended nor a success because we can point to some positive actions and movements away from brutality. It is not going to be carried out in the same way in every country where violations have occurred; yet when those violations occur, they are not going to be ignored. For those who argue that the human rights policy has been all rhetoric and no action, let me assure you that neither the governments nor the dissidents in countries where repression exists would agree with that statement. Most governments would like us to do less; many dissidents would like us to do more. But all understand that a different drum is sounding in Washington. The drum sounds when Anatoly Scharansky is arrested in the Soviet Union for seeking freedom. The drum sounds when Kim Dae Jung is imprisoned in South Korea for speaking out for democracy. The drum sounds when newspaper editors in Argentina and Uruguay disappear. The drum sounds when Steve Biko is imprisoned in South Africa and becomes a martyr in the struggle for equality. It will have different beats and be heard in different ways, but it will be heard. No nation can engage in gross violations of the rights of its citizens without having its relations with the United States affected in fundamental ways.

Within the government bureaucracy, human rights have been accorded a higher priority. There is now an independent Bureau for Human Rights and Humanitarian Affairs in the State Department, headed by an assistant secretary, with access to the Secretary of State and to the President. The Bureau's staff has been growing even during a time of budget pinching. Its officers try to ensure that human rights concerns are included in all policy goals and strategy papers. In the National Security Council, a person has been separately charged with human rights responsibilities. In the State Department, each bureau now must have a full-time, permanent human rights officer who works in liaison with the Bureau. An interagency group has been established, chaired by the Deputy Secretary of State, with representatives from throughout the government, to factor human rights concerns into our bilateral economic assistance programs, and into our positions on votes in the international financial institutions. 
There has been a series of reporting instructions to embassies in the field to emphasize the need for information, and to make the ambassador personally responsible for implementation of the human rights policy. In contrast with prior practice, these changes are of some importance. Several years ago, for example, when an ambassador to Chile raised human rights concerns with the President of the junta of that country, a high official in the State Department wrote across the cable reporting the conversation, "No more political science lectures." The point is that now ambassadors have been instructed to take account of the human rights condition in the country, to raise such concerns with the government, and to take specific steps when instructed on behalf of human rights.

The Assistant Secretary of State for Human Rights and Humanitarian Affairs now has full membership on all interagency committees concerning security assistance and arms transfers. Our Bureau has responsibility for making separate reviews of proposals to provide export licenses for the shipping of commercial arms. And we have a negative presumption, now official policy, against transfers to police, law enforcement, or internal security forces of countries engaged in gross violations of human rights.

These changes reflect shifts in the ways that decisions are made. It is somewhat comparable to acupuncture in that each of these individual developments is a needle inserted into the decision making process with the ideal outcome a more harmonious policy, reflecting an increased priority for human rights.

If these are the ways that the process is changing, it is legitimate to ask about the outcome. In the international arena, as I already reported, the President has signed and submitted to the Senate for ratification, the International Covenants on Human Rights. In the United Nations and the Organization of American States, we have sought to change the role of the United States into a far more active one in pressing for decisions to promote human rights. We also have strengthened our relations with non-governmental organizations.

In the long run, it is in the international arena in which the enforcement of human rights standards ultimately must occur. Now in Geneva, the Human Rights Commission is meeting. The session began February 6 th and will close March 10th [1978-ed.]. One of the proposals that we are strongly pressing is the creation of a United Nations High Commissioner for Human Rights. That proposal was first introduced in the early 1960s. We may not achieve its creation this year, but the international community is definitely heading in that direction. The functions of a High Commissioner are beginning to be accepted as legitimate; an example is the need for coordination within the United $\mathrm{Na}$ tions system of all human rights activities and programs within the office of the Secretary General. Whether the post created is called a High Commissioner, which we advocate, or whether there is a Coordinator or an Under- 
secretary in charge, the point is that the post, its role and functions are gaining acceptance, although slowly.

In addition, we hope that there can be a new agency or institution, an international clearinghouse on human rights, specifically developed to provide independent up-to-date information and reports on human rights conditions in countries around the world. As you know, the Department of State is now required by law to submit to Congress reports on the status of human rights in countries which receive economic or security assistance from the United States. Several problems exist with regard to our submitting public reports to the Congress. First, there is always going to be criticism that because of other interests the reports are not strong enough. Still others will criticize the reports for being too strong. What is evident is that reports prepared by a government will have less credibility than reports prepared by an international, independent body. Consequently, we are exploring the possibility of independent funding by a series of governments, organizations, and foundations to try to create this institution. We hope that others will see the clearinghouse as an additional resource to promote greater respect for human rights in the international community.

I will now describe how the human rights policy works bilaterally. First, we look at countries in light of the broad range of rights enumerated in the Universal Declaration. We look with particular intensity at reports of violations of the rights of the integrity of the person. By that we mean torture, arbitrary imprisonment, denial of a fair public trial, and invasion of the home. We look at the frequency of the violations, the evidence of government responsibility, and the trend.

Second, we focus on economic and social rights, where we examine the extent to which countries are seeking to meet the basic human needs of their people.

Third, we look at fundamental civil and political liberties, such as freedom of speech, association, assembly, movement, the right to participate in government.

Once we determine that a country is engaged in serious human rights violations, we undertake a strategy of vigorous diplomacy. We communicate directly to the government, usually at the highest levels, our specific concerns about the human rights situation. That has occurred with regard to nearly every country that we consider has engaged in serious violations, including those with whom we have other important interests. By raising the issue in the context of our overall relationship, stating clearly the priority that both the executive and the legislative branches place on human rights, we raise it inevitably to the center of diplomatic interchange. Once raised, the issue cannot easily be eliminated from that dialogue.

Frequently it also means that human rights concerns are raised to the cen- 
ter of that country's decision making. Our statements are often underlined by symbolic acts: trips by senior officials, high level discussions with individuals of the political opposition-sometimes in exile-and the structuring of our cultural and exchange programs to reflect human rights concerns.

1 shall give you an example of the difference this has made. Several years ago when I was working in the Senate, I was part of a refugee investigation subcommittee which visited Chile in 1974 after the junta had taken over. While in Chile, we visited some of the prisons and, in one, saw the former foreign minister of the Allende government. At that time, the United States was viewed-and rightly so-as a government supporting the junta with military and economic assistance. In fact, as I recall, the previous Administration had asked that 85 percent of our PL-480 Title I be directed to Chile. Several months ago, the same former foreign minister I visited met with the Deputy Secretary of State to discuss human rights problems in Chile. That meeting sent a very clear message to the Chilean Government of the kinds of concerns motivating the foreign policy establishment in the United States today.

At times, public comment directly, condemning human rights violations takes place. With regard to some countries, it is the only way to express our concerns.

When our relationship with countries includes military and economic assistance, we have communicated frankly and clearly the legislative restrictions enacted by the Congress. We also have made policy decisions, recently reiterated by the President, to channel a growing proportion of our economic assistance to countries that respect the human rights of their citizens or that have serious unmet human development needs. The converse is also true. Countries with poor human rights records can expect to see a declining proportion of our assistance. The Deputy Secretary said recently that "when countries we assist consistently curtail human rights, and where our preferred diplomatic efforts have been unavailing, we must consider restrictions on the flow of our aid, both overall levels and individual loans or grants." In keeping with this policy guideline, during the past year, we have deferred bilateral economic assistance to some countries and halted economic assistance to others. We opposed twenty loans in the international financial institutions to countries engaging in serious and persistent violations of human rights. We have informed countries that if their loans were brought before the board, we would oppose them; as a result half a dozen loans were withdrawn from consideration. We have advised the Export-Import Bank and the Overseas Private Investment Corporation of our views concerning human rights conditions in various countries. At the same time, we have made those countries aware that our actions were related to the absence of improvements in human rights practices of the government.

During recent months we also have reduced or declined to increase our 
military aid to a number of countries. We have refused to sign military assistance agreements that had been approved by the Congress or to issue export licenses for commercial arms sales. We have denied crowd control equipment, radar surveillance devices, armored cars and personnel carriers, handguns, machine guns, automatic rifles and ammunition to national police agencies in countries engaged in human rights violations.

These actions have reflected a change in policy. Obviously, none of these decisions is easy. Human rights objectives always must be pursued with an awareness of other fundamental interests of the United States. The diversity of the history, culture and stages of development of different countries will make the choice of the best approach to promote change difficult.

The goal of the policy always is to be effective, to ease the suffering of individuals and to open the political process. We cannot take credit for specific changes. According to the year-end report of the International League for Human Rights, a non-governmental organization active in the human rights field, the following changes have taken place: "First, within the past year, human rights has for the first time become a subject of national policy debate in many countries. Second, human rights concerns have been the focus of greater discussion in international organizations. Third, the world media have focused on international human rights issues to a greater extent than ever before. Fourth, consciousness of human rights among the peoples of the world has increased significantly. And fifth, there has been an easing of repression in a substantial number of cases." The League cited twenty-nine specific cases of improvement and concluded: "A most significant factor has been President Jimmy Carter's affirmation and advocacy of the United States' commitment to the international protection of human rights and the United States' encouragement of other states to undertake a similar commitment."

The reason that it is important to recognize the kinds of changes that have taken place-prisoners released, political liberalization, a lifting of censorship, and in one or two countries, even a return to democracy-is not to claim credit, but to argue that the posture and actions of the United States can contribute to or impede change. The tragedy is that, in the recent past, we failed to acknowledge the legitimacy of human rights as a foreign policy objective. While its legitimacy is no longer at issue, the human rights objective is still overridden by competing objectives.

Repression continues to be widespread and unchecked in numerous countries. Men and women remain behind bars because they will not remain silent and because they aspire to be free. Governments using torture and brutality violate virtually every right contained in the Universal Declaration of Human Rights. In too many countries, fundamental legal protection of the individual either is so fragile as to be meaningless or does not exist. In conclusion, let 
me paraphrase the words of Winston Churchill. When we look at the movement towards respect for human rights, we are neither at the end nor even the beginning of the end, but perhaps we are approaching the end of the beginning. 